\title{
Electrospray Mass Spectral Fragmentation Study of N,N'-Disubstituted Imidazolium Ionic Liquids
}

\author{
Alain Lesimple and Orval Mamer \\ Mass Spectrometry Unit, McGill University, Montreal, Quebec, Canada \\ Weishi Miao and Tak Hang Chan \\ Department of Chemistry, McGill University, Montreal, Quebec, Canada
}

\begin{abstract}
The tandem positive electrospray mass spectrometry $\left(\mathrm{ESMS}^{\mathrm{n}}\right)$ fragmentation of ionic liquids incorporating the 1-methyl-imidazolium ring substituted on $\mathrm{N}^{\mathrm{II}}$ with an alkyl chain functionalized with an alcohol, carboxylic acid, or an iodobenzyl or iodobenzoyl ester is presented for the first time. The influence of chain length and function is studied. Esterified structures led to intense CID fragments lacking the imidazolium ring allowing full characterization of the ester moiety. Fragment ion compositions for this interesting and newly important class of compounds are established through accurate mass data and deuterium labeling. The presence of the cationic ring system produces intense even electron molecular cations in electrospray that undergo multiple stages of CID to yield fragments which often are radical cations. Unusual losses of methyl and hydrogen radicals are frequently noted. (J Am Soc Mass Spectrom 2006, 17, 85-95) (c) 2005 American Society for Mass Spectrometry
\end{abstract}

I onic liquids (ILs) have recently become the subject of considerable interest because of their potential use in "green" chemistry. Due to their low vapor pressure, high thermal stability, ease of recovery facilitating recycling, and applicability to both chemical and enzymatic catalytic processes, ILs have been advocated as reaction media to replace volatile organic solvents (for recent reviews see [1]). Room-temperature ionic liquids have now been explored as media for electrochemical technologies [2], chemical extractions [3], various other industrial processes [4] for analytical purposes [5], and, for example, as matrices in matrixassisted laser desorption ionization [6]. More recently, the use of imidazolium ILs which constitute with pyridinium ILs the two main IL families as soluble supports for organic synthesis to facilitate phase separation and purification has also been demonstrated [7]. The special interest that these compounds have for study by electrospray mass spectrometry (ESMS) resides in the inherent permanent charge they carry, which gives rise to uncommon modes of collision induced dissociation (CID).

To our knowledge, only a few published reports deal with ESMS of imidazole based ILs [8-11], and they incompletely describe their properties in the mass spectrometer and their fragmentation pathways. We report here the tandem ESMS $\left(\mathrm{ESMS}^{\mathrm{n}}\right)$ fragmentation of sev-

Published online December 15, 2005

Address reprint requests to Dr. O. Mamer, Mass Spectrometry Unit, McGill University, 740 Dr. Penfield, Suite 5300, Montreal, Quebec H3A 1A4, Canada. E-mail: orval.mamer@mcgill.ca eral ILs substituted on $\mathrm{N}^{\mathrm{II}}$ of 1-methylimidazole with alkyl chains functionalized with hydroxyl, carboxylic acid, or ester groups (Scheme 1). Their elemental compositions are confirmed through accurate mass measurement data and their fragmentation pathways are studied through isotope labeling and accurate $\mathrm{MS}^{2}$ for Compounds 1 to 4 and through accurate $\mathrm{MS}^{\mathrm{n}}$ scans for Compounds 5 to 8 .

In addition, we measured fragment ion intensities expressed as percent total ion current as a function of collision cell voltage as described by Butcher et al. [12]. These breakdown graphs allow an estimation of the relative energy of transitions and can be used not only to interpret fragmentation pathways in the manner used to illuminate the homolytic mechanisms proposed for the thermolysis of neutral species [13] but also to allow the selection of optimal conditions for analysis by multiple reaction monitoring.

\section{Experimental}

\section{Compounds}

All compounds were prepared following previously described procedures [7c]. Analytical characterization is given in reference [7c] for Compounds $\mathbf{1}$ and $\mathbf{5}$ and in the Supplementary Material section (which can be found in the electronic version of this article) for the others.

Deuterium oxide, $\left[{ }^{2} \mathrm{H}_{3}\right]$-iodomethane and $\left[{ }^{2} \mathrm{H}_{4}\right]$-imidazole were obtained from CDN Isotopes (Pointe- 


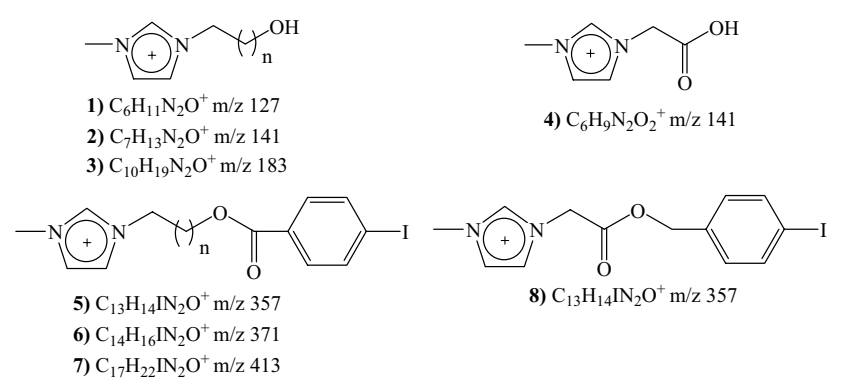

Scheme 1. Structures of compounds studied.

Claire, Quebec, Canada), the other starting materials (imidazole, 2-bromoethanol, 3-bromopropanol, 6-bromohexanol, and chloroacetic acid) were obtained from Aldrich Chemical (Oakville, Ontario, Canada). Labeled derivatives were synthesized by the microwave condensation method [14] and the resulting mixtures were analyzed in ESMS ${ }^{2}$ without further purification. Elemental compositions of all the studied compounds were confirmed in high-resolution ES-FTMS.

\section{Instrumentation}

Low-resolution ESMS and ESMS ${ }^{2}$ analyses were carried out in positive ion mode using a Micromass Quattro II triple quadrupole mass spectrometer (Manchester, UK) equipped with an electrospray source. Samples, dissolved in $80 \%$ acetonitrile, $20 \% \mathrm{H}_{2} \mathrm{O}$ containing $0.5 \%$ formic acid, were infused at a flow rate of $120 \mathrm{ml} / \mathrm{h}$. Spectra were accumulated in multi-channel analysis (MCA) mode for $1 \mathrm{~min}$ at each collision energy (CE), smoothed, and background subtracted. Data analyses were carried out using MassLynx version 3.5 software.
Nitrogen was used as drying gas $(400 \mathrm{l} / \mathrm{h})$ and nebulizing gas $(201 / \mathrm{h})$. The ES capillary was set at $3.1 \mathrm{kV}$ while the MS analysis was carried out at a cone voltage of $25 \mathrm{~V}$, a scan rate of $300 \mathrm{Da} / \mathrm{s}$ with an inter-scan delay of $0.1 \mathrm{~s}$, and a scan range of 120-1000 Da. The resolving power was set to obtain unit resolution. CID analyses were performed in argon (pressure $1.2 \times 10^{-3} \mathrm{mbar}$ ) with CE ranging from $0 \mathrm{eV}$ to 60 or $100 \mathrm{eV}$ with $5 \mathrm{eV}$ increments (laboratory frame of reference). Breakdown graphs are constructed by plotting percent total ion current (TIC) for each ion against the collision cell voltage at which each spectrum is measured, and these are available as Supplementary Material. ESMS spectra of all nonlabeled compounds and combined ESMS ${ }^{2}$ scans of energies above $15 \mathrm{eV}$ are available as Supplementary Material.

High-resolution measurements were made in positive ion electrospray mode with an IonSpec 7.0 tesla FTMS (Lake Forest, CA) calibrated with polyethylene glycol 300. The instrument was equipped with a Zspray source from Waters Corporation (Milford, MA), an accumulation hexapole, no collision cell, a quadrupole ion guide, a standard cylindrical ion cyclotron resonance (ICR) cell, and Omega 8 software. The analyses employed a direct infusion flow rate of 2 to 3 $\mathrm{ml} / \mathrm{min}$, a capillary voltage of $3800 \mathrm{~V}$ and a cone voltage of $45 \mathrm{~V}$. Ions were accumulated in the hexapole for 300 to $1500 \mathrm{~ms}$ with a rod voltage of $120 \mathrm{~V}$. For the transfer of ions through the quadrupole ion guide, the low mass range coil with a frequency of $1985 \mathrm{kHz}$ was used. Parameter setups were manually built to optimize the $\mathrm{MS}^{\mathrm{n}}$ analyses. For $\mathrm{MS}^{2}$ scans, sustained off resonance ionization collision induced dissociation (SORICID) was used with an arbitrary waveform for expel-

Table 1. Accurate mass measurements for Compounds 1 to 8

$\begin{array}{lllll} & & & \\ & & & \\ & & & \\ & & & & \\ & & & & \\ \end{array}$




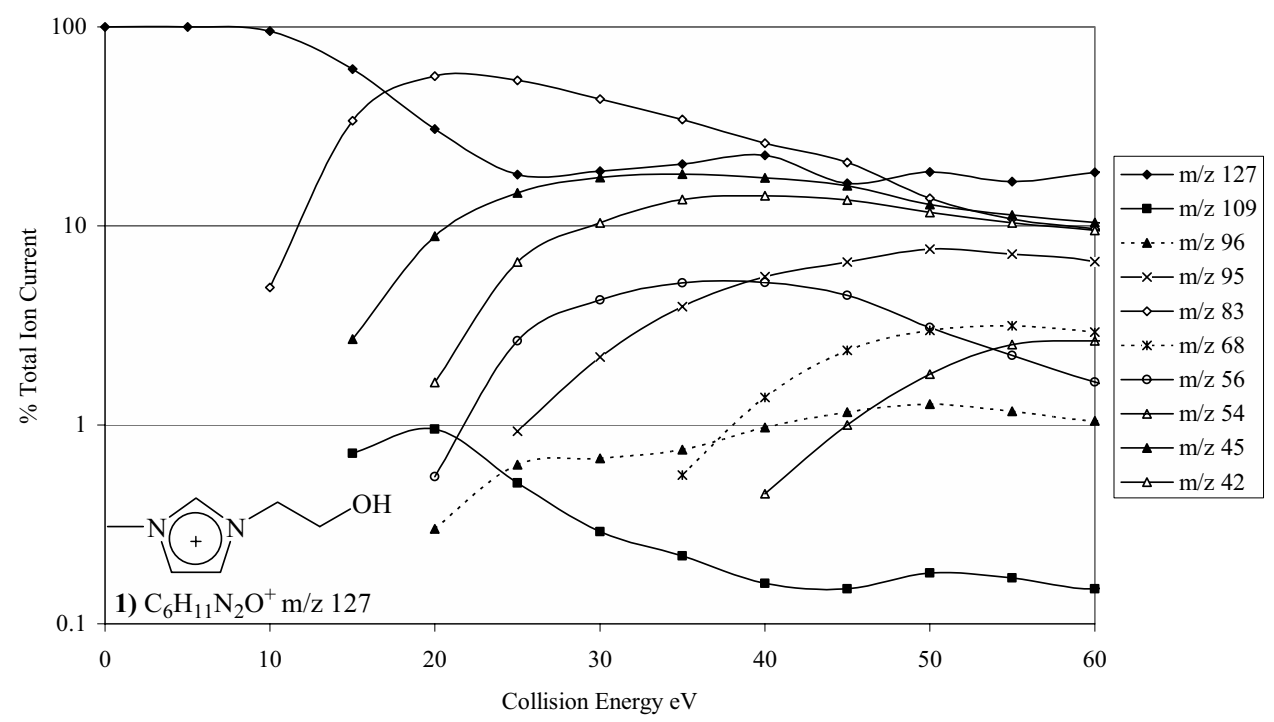

Figure 1. Breakdown graph for 1. For the sake of clarity, some minor ions have been removed but are available in the Supplementary Material. Solid lines represent even electron ions, dotted lines represent odd electron ions.

ling from the ICR cell all the ions outside a window of $\pm 10 \mathrm{Th}$ around the ion of interest and an isolation function was used to expel, within this window, ions more than 0.9 Th from the selected precursor. A $500 \mathrm{~ms}$ rf pulse $\left(1-3 \mathrm{~V}_{p-p}\right)$ SORI with an offset frequency $1 \mathrm{kHz}$ lower than the resonant ion cyclotron frequency was used with a nitrogen gas pulse of $100 \mathrm{~ms}$ starting synchronously with the SORI rf pulse.

For $\mathrm{MS}^{3}$ and $\mathrm{MS}^{4}$ experiments, the same steps were followed without the additional isolation function. For detection, ion excitation was done through an arbitrary waveform in a range of 25 to $1000 \mathrm{~m} / \mathrm{z}$ with an ampli-

Table 2. Compositions of CID fragments obtained for Compound 1 and its labeled analogs

\begin{tabular}{|c|c|c|c|}
\hline Composition & $\begin{array}{c}\mathrm{X}=\mathrm{CH}_{3} \\
\mathrm{Y}=\mathrm{H}\end{array}$ & $\begin{array}{c}X=\mathrm{C}^{2} \mathrm{H}_{3} \\
\mathrm{Y}=\mathrm{H}\end{array}$ & $\begin{array}{c}X=\mathrm{C}^{2} \mathrm{H}_{3} \\
\mathrm{Y}={ }^{2} \mathrm{H}\end{array}$ \\
\hline $\mathrm{C}_{5} \mathrm{H}_{5} \mathrm{~N}_{2} \mathrm{OXY}_{3}{ }^{+}$ & 127 & 130 & 133 \\
\hline $\mathrm{C}_{5} \mathrm{H}_{3} \mathrm{~N}_{2} \mathrm{XY}_{3}{ }^{+}$ & 109 & 112 & 115 \\
\hline $\mathrm{C}_{4} \mathrm{H}_{2} \mathrm{~N}_{2} \mathrm{XY}_{3}^{+\cdot}$ & 96 & 99 & 102 \\
\hline $\mathrm{C}_{4} \mathrm{HN}_{2} \mathrm{XY}_{3}{ }^{+}$ & 95 & 98 & 101 \\
\hline $\mathrm{C}_{3} \mathrm{HN}_{2} \mathrm{XY}_{3}{ }^{+}$ & 83 & 86 & 89 \\
\hline $\mathrm{C}_{3} \mathrm{HNY}_{3}{ }^{+\cdot}$ & 68 & 68 & 71 \\
\hline $\mathrm{C}_{2} \mathrm{HNXY}_{2}^{+}$ & 56 & 59 & 61 \\
\hline $\mathrm{C}_{2} \mathrm{H}_{4} \mathrm{OH}^{+}$ & 45 & 45 & 45 \\
\hline $\mathrm{C}_{2} \mathrm{H}_{2} \mathrm{OH}^{+}$ & 43 & nd & nd \\
\hline $\mathrm{C}_{2} \mathrm{HNY}_{3}{ }^{+}$ & 42 & 42 & 45 \\
\hline $\mathrm{CNXY} \mathrm{Y}^{+}$ & 42 & 45 & 46 \\
\hline
\end{tabular}

Bold ions have significant intensity only at high CE as correlated by breakdown graphs in Supplementary Material nd: not detected tude of $140 \mathrm{~V}(\mathrm{~b}-\mathrm{p})$, the ADC rate for MS was $2 \mathrm{MHz}$ for a scan range of $m / z 108-1000$ and $16 \mathrm{MHz}$ for $\mathrm{MS}^{\mathrm{n}}$ for a scan range of $m / z 25-500$. Transients were $2 \mathrm{M}$ data points long and up to 10 scans were accumulated. To allow the pressure in the ICR cell to come back to its nominal value of $1-210^{-10}$ torr before the detection step, a waiting time of $4 \mathrm{~s}$ was used after the last gas pulse. The $\mathrm{MS}^{\mathrm{n}}$ experiments were calibrated using the precursor ion as internal reference.

\section{Results and Discussion}

Table 1 presents the accurate mass measurements obtained for unlabeled Compounds $\mathbf{1}$ to $\mathbf{8}$ and the labeled analogs of 1 to 4 .

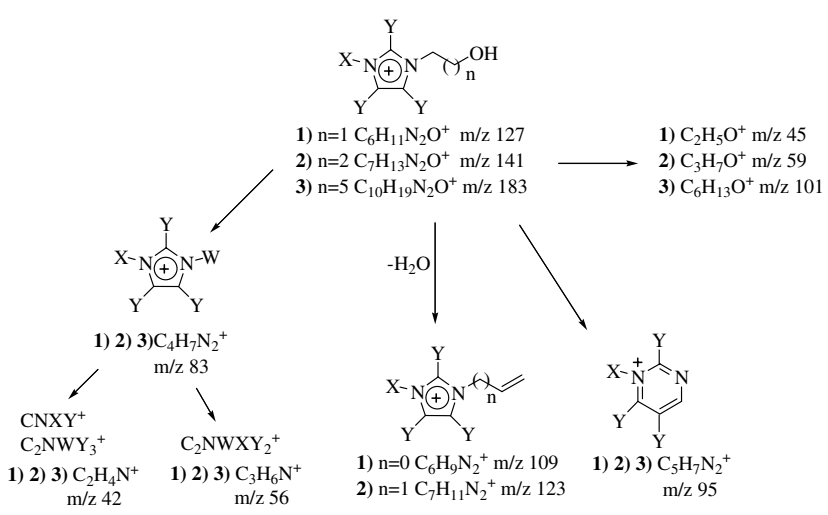

Scheme 2. CID fragmentation scheme and product ion compositions proposed for 1, 2, and 3. Ion compositions and masses are those for the unlabeled compounds. "W" represents the hydrogen atom transferred to $\mathrm{N}^{\mathrm{II}}$ from the leaving side-chain. $\mathrm{X}$ and $\mathrm{Y}$ are defined in Table 1. 
Table 3. Accurate masses obtained for the principal fragment produced in CID of Compounds 1, 2 and 3

\begin{tabular}{|c|c|c|c|c|c|}
\hline & & & \multicolumn{3}{|c|}{ Found (error: ppm) } \\
\hline & Proposed formula & Calculated & 1 & 2 & 3 \\
\hline $\begin{array}{l}\mathrm{X}=\mathrm{CH}_{3}, \mathrm{Y}=\mathrm{H}, \mathrm{n}=1 \\
\mathrm{X}=\mathrm{C}^{2} \mathrm{H}_{3}, \mathrm{Y}=\mathrm{H}, \mathrm{n}=2 \\
\mathrm{X}=\mathrm{C}^{2} \mathrm{H}_{3}, \mathrm{Y}={ }^{2} \mathrm{H}, \mathrm{n}=5\end{array}$ & $\begin{array}{l}\mathrm{C}_{4} \mathrm{H}_{7} \mathrm{~N}_{2}^{+} \\
\mathrm{C}_{4}{ }^{2} \mathrm{H}_{3} \mathrm{H}_{4} \mathrm{~N}_{2}^{+} \\
\mathrm{C}_{4}{ }^{2} \mathrm{H}_{6} \mathrm{H}_{1} \mathrm{~N}_{2}^{+}\end{array}$ & $\begin{array}{l}83.06037 \\
86.07921 \\
89.09804\end{array}$ & $\begin{array}{l}83.0604(0.2) \\
86.0792(0.3) \\
89.0981(0.8)\end{array}$ & $\begin{array}{l}83.0607(4.4) \\
86.0792(0.0) \\
89.0986(6.4)\end{array}$ & $\begin{array}{l}83.0605(1.3) \\
86.0796(4.6) \\
89.0979(-1.8)\end{array}$ \\
\hline
\end{tabular}

\section{Fragmentation of Compounds 1, 2, and 3}

These ILs bear an alcohol function and may be useful as media to dissolve highly polar biomolecules such as carbohydrates and nucleic acids [15] and as substrates for organic syntheses [7c, d]. Structures and compositions of fragment ions produced from these ILs are established through SORI CID MS ${ }^{\mathrm{n}}$ in the FTMS and by CID in the triple quadrupole instrument with deuterium labeled analogs synthesized with trideuteromethyl iodide and unlabeled or ${ }^{2} \mathrm{H}_{4}$ labeled imidazole.
Figure 1 is the breakdown plot for $\mathbf{1}$ which is useful in the construction of its fragmentation scheme. The main fragments of Compound $\mathbf{1}$ and its labeled analogs are presented in Table 2. With increasing CE, $\mathrm{m} / \mathrm{z} 127$ begins to decline at $10 \mathrm{eV}$, coinciding with the onset of appearance of $\mathrm{m} / \mathrm{z} 83 . \mathrm{M} / \mathrm{z} 83$ maximizes at $\sim 20 \mathrm{eV}$ and as it declines in intensity, the intensities of $m / z 42$ and 56 increase together, suggesting a precursor-product relationship. $M / z 45$ also appears early in the loss of $m / z 127$ intensity, and this suggests that like $m / z 83$, it is a first
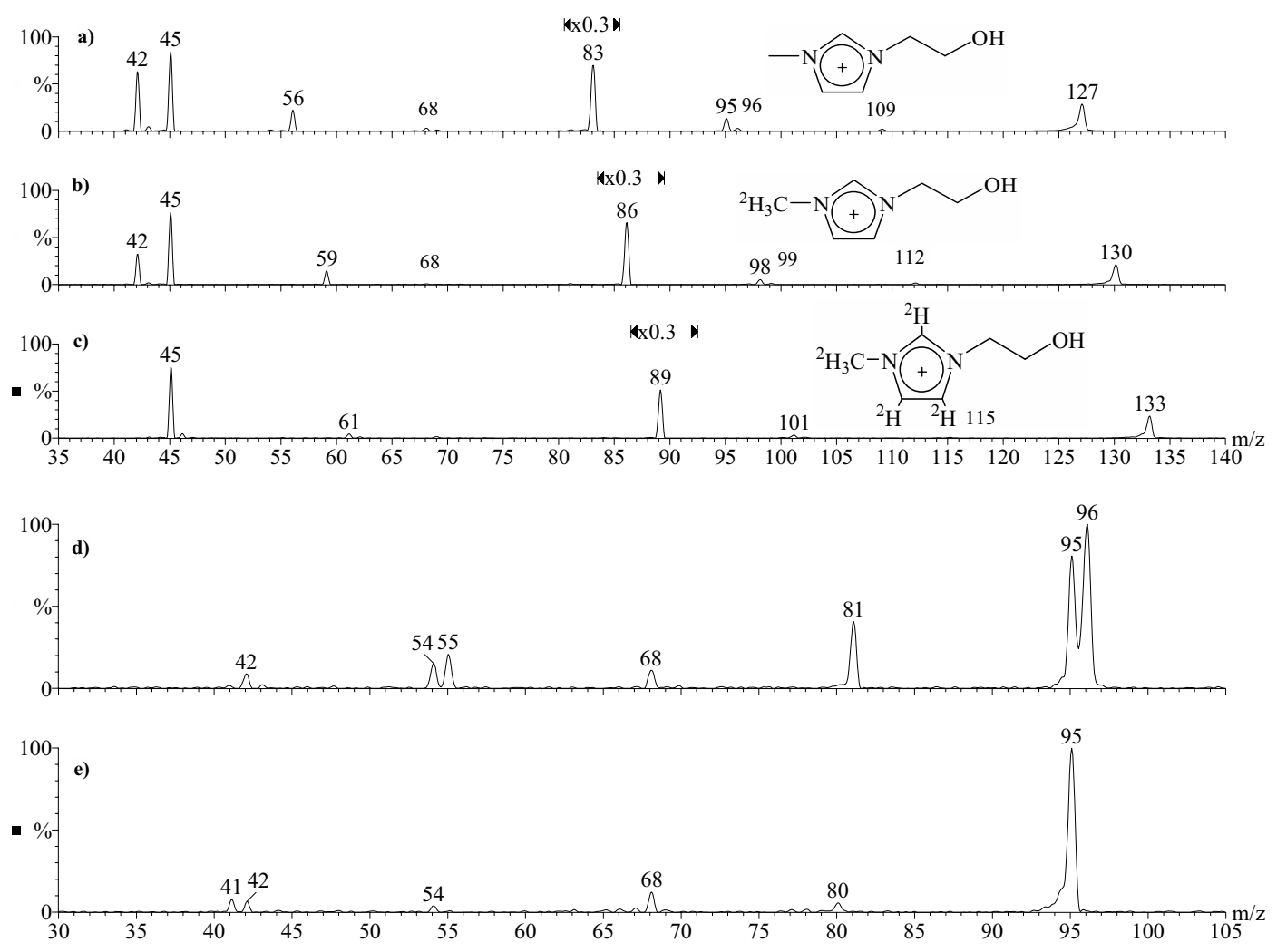

Figure 2. Influence of labeling on the CID of $\mathbf{1}$ at $\mathrm{CE}=25 \mathrm{eV}$ (a) conventional $\mathrm{MS}^{2}$ of $\mathbf{1}$, (b) and (c) $\mathrm{MS}^{2}$ of deuterium labeled 1. Ion intensities in the range $\mathrm{m} / \mathrm{z} 82$ to 90 are multiplied by 0.3 to increase the visibility of other ions. (d) MS $\mathrm{M}^{2}$ spectrum of $\mathrm{m} / \mathrm{z} 96$ obtained by in source decomposition of 1 showing loss of hydrogen and methyl radicals from $m / z$ 96. (e) $\mathrm{MS}^{2}$ spectrum of $\mathrm{m} / \mathrm{z} 95$ obtained by in source decomposition of $\mathbf{1}$ showing loss of methyl radical from $\mathrm{m} / \mathrm{z} 95$. 

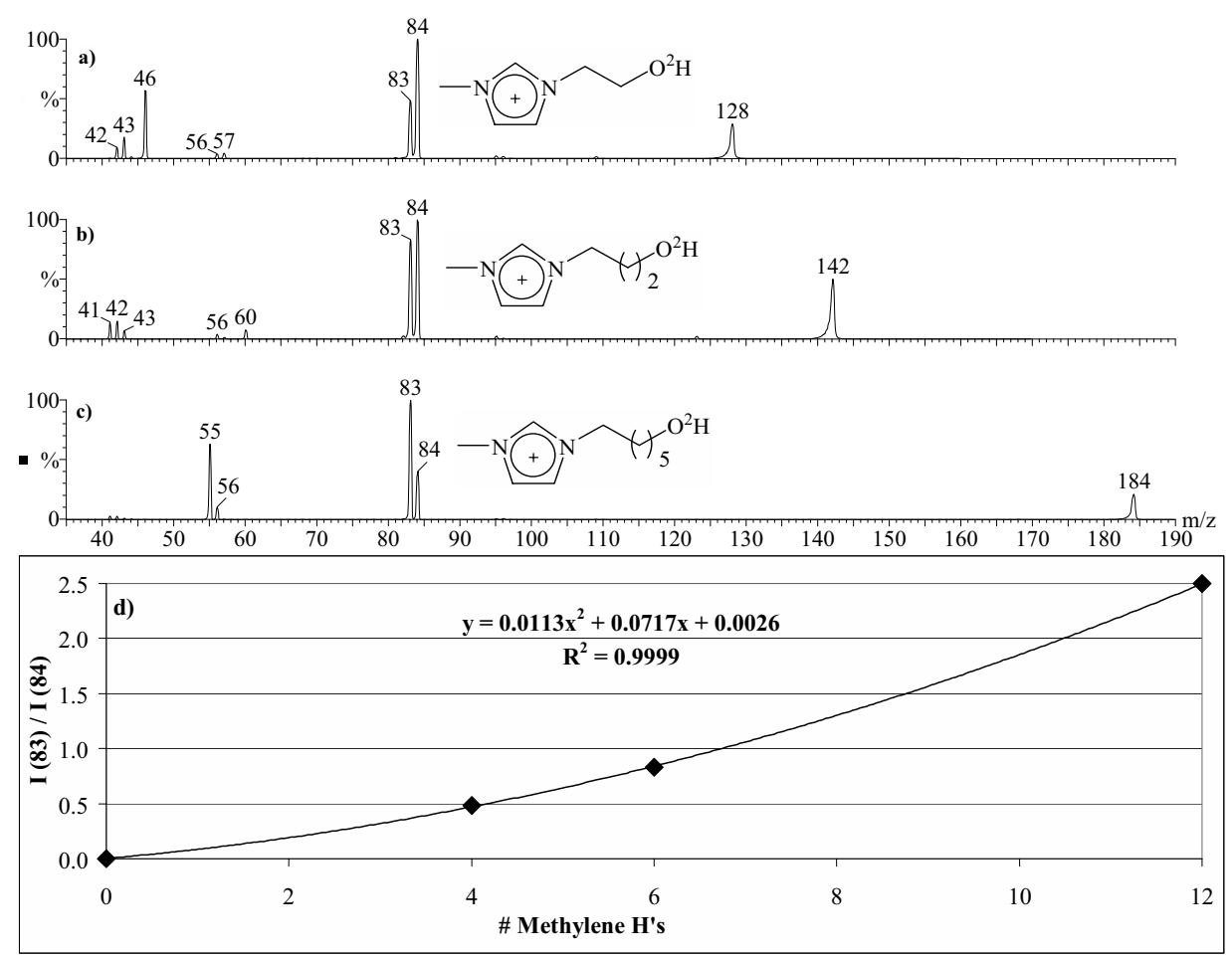

Figure 3. $\mathrm{MS}^{2}$ spectrum at CE $25 \mathrm{eV}$ in deuterated solvent of the IL parent ions of $\mathbf{1}$ in (a), $\mathbf{2}$ in (b), 3 in (c). Panel (d) correlates the number of methylene hydrogens in the side-chain with the ratio of the intensities of $\mathrm{m} / \mathrm{z} 83$ and 84

generation fragment of $m / z$ 127. One can note that the intensity of $\mathrm{m} / \mathrm{z} 127$ does not fall to zero but rather remains at $\sim 20 \%$ TIC above $25 \mathrm{eV}$. We interpret this as an indication that $\mathrm{m} / \mathrm{z} 127$ undergoes a rearrangement to a more stable ion above $25 \mathrm{eV}$. The appearance of $\mathrm{m} / \mathrm{z}$ 95 coincides with the point at which $\mathrm{m} / z 127$ ceases its decline and does not fall appreciably with increasing $\mathrm{CE}$, suggesting that it is a reasonably stable ion with perhaps some aromatic stabilization derived from its possibly rearranged precursor. Scheme 2 correlates these observations, and includes additional aspects inferred from high-resolution data and CID of labeled $\mathbf{1}$.

In the breakdown graphs of $\mathbf{2}$ and $\mathbf{3}$ (Supplementary Material), similar correlations are noted and are supportive of the fragmentation pathway proposed in Scheme 2. The parent ions $(\mathrm{m} / \mathrm{z} 141$ and 183$)$ begin to lose intensity at $10 \mathrm{eV}$, and, like $\mathrm{m} / \mathrm{z} 127$ in 1, stabilize

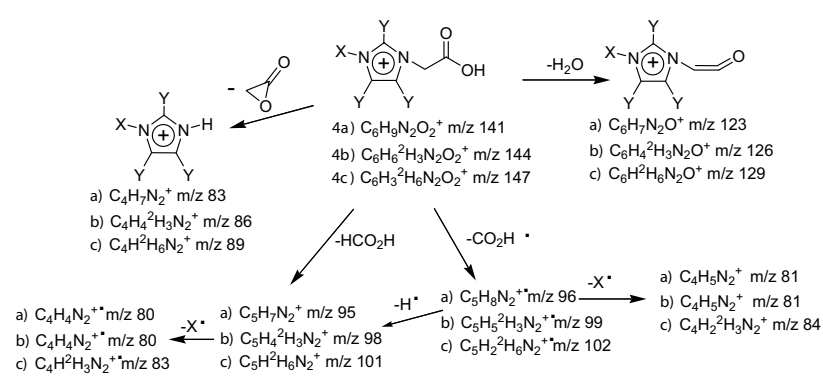

Scheme 3. Proposed fragmentation pathway for 4. $\mathrm{X}=\mathrm{CH}_{3}$ for $4 \mathrm{a}$, and $\mathrm{C}^{2} \mathrm{H}_{3}$ for $4 \mathrm{~b}$ and $4 \mathrm{c}$. $\mathrm{Y}=\mathrm{H}$ for $4 \mathrm{a}$ and $4 \mathrm{~b}$, and ${ }^{2} \mathrm{H}$ for $4 \mathrm{c}$. after $25 \mathrm{eV}$ at $\sim 20$ and $6 \%$ of TIC, respectively. $M / z 95$ is a less intense fragment in $\mathbf{2}$ and 3, and its intensity correlates inversely with alkyl chain length.

By accurate mass measurement, $m / z$ 83, which is the base peak for unlabeled 1 to 3 in a wide energy range is $\mathrm{C}_{4} \mathrm{H}_{7} \mathrm{~N}_{2}{ }^{+}$. Their $\mathrm{C}^{2} \mathrm{H}_{3}$ and ${ }^{2} \mathrm{H}_{6}$ analogs are shifted to $\mathrm{m} / \mathrm{z}$ $86\left(\mathrm{C}_{4}{ }^{2} \mathrm{H}_{3} \mathrm{H}_{4} \mathrm{~N}_{2}{ }^{+}\right)$and $m / z 89\left(\mathrm{C}_{4}{ }^{2} \mathrm{H}_{6} \mathrm{HN}_{2}{ }^{+}\right)$, respectively (Table 3, Figure 2). This fragmentation is similar to the scission of the alkyl $\mathrm{C}-\mathrm{N}$ bond of $\mathrm{N}$-alkyl pyrroles with concomitant transfer of a hydrogen from the leaving alkyl moiety to the nitrogen $[16,17]$ to yield in our study the 1-methyl-3-H-imidazolium ion. The side chains of $\mathbf{1}$ to 3 are terminated by a hydroxyl group and the question of the origin of the transferred hydrogen arises. To elucidate this point, we recorded the CID scans of Compounds $\mathbf{1}$ to 3 in a deuterated solvent (ACN $80 \% / \mathrm{D}_{2} \mathrm{O} 19 \%$ /formic acid 1\%) which exchanges the labile proton of the hydroxyl group. This produced two ions at $\mathrm{m} / \mathrm{z} 83$ and 84 (Figure $3 \mathrm{a}, \mathrm{b}, \mathrm{c}$ ) having relative intensities dependant on the alkyl chain length. The origin of the hydrogen $\mathrm{W}$ transferred from the side-chain on $\mathrm{N}^{\mathrm{II}}$ is directly correlated to the number of methylene group hydrogens in the side-chain and alcohol function through a second-order relationship (Figure $3 \mathrm{~d}$ ). The migrating proton has been shown to originate in various positions along the alkyl chain in an analogous fragmentation in the electron ionization spectrum of N-n-butylpyrrole [17], however to the best of our knowledge this is the first time that the influence of the chain length terminated with an alcohol function 
Table 4. Compositions of SORI CID fragments obtained for Compound 4 and labeled analogs

\begin{tabular}{|c|c|c|c|c|c|c|}
\hline \multirow{2}{*}{$\begin{array}{l}\text { Composition } \\
\text { Proposed formula }\end{array}$} & \multicolumn{2}{|c|}{ 4a) $\begin{array}{c}X=\mathrm{CH}_{3} \\
Y=H\end{array}$} & \multicolumn{2}{|c|}{ 4b) $\begin{aligned} \mathrm{X}=\mathrm{C}^{2} \mathrm{H}_{3} \\
\mathrm{Y}=\mathrm{H}\end{aligned}$} & \multicolumn{2}{|c|}{ 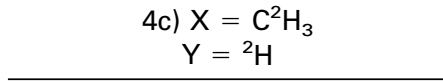 } \\
\hline & Calculated & Found (error: ppm) & Calculated & Found (error: ppm) & Calculated & Found (error: ppm) \\
\hline $\mathrm{C}_{6} \mathrm{HN}_{2} \mathrm{OXY}_{3}^{+}$ & 123.0553 & $123.0554(1.2)$ & 126.0741 & $126.0742(1.0)$ & 129.0929 & $129.0931(1.4)$ \\
\hline $\mathrm{C}_{4} \mathrm{H}_{2} \mathrm{~N}_{2} \mathrm{XY}_{3}^{+\cdot}$ & 96.0682 & $96.0685(3.2)$ & 99.0870 & $99.0875(4.6)$ & 102.1059 & $102.1063(4.3)$ \\
\hline $\mathrm{C}_{4} \mathrm{HN}_{2} \mathrm{XY}_{3}^{+}$ & 95.0604 & 95.0607 (3.8) & 98.0792 & $98.0793(0.8)$ & 101.0980 & $101.0984(3.8)$ \\
\hline $\mathrm{C}_{3} \mathrm{HN}_{2} \mathrm{XY}_{3}{ }^{+}$ & 83.0604 & $83.0608(5.7)$ & 86.0792 & $86.0799(7.7)$ & 89.0980 & $89.0987(7.0)$ \\
\hline $\mathrm{C}_{4} \mathrm{H}_{2} \mathrm{~N}_{2} \mathrm{Y}_{3}^{+}$ & 81.0447 & nd & 81.0447 & $81.0449(2.8)$ & 84.0636 & $84.0635(-0.5)$ \\
\hline
\end{tabular}

nd: not detected

is studied. To discount the possibility that proton exchange may competitively occur in position 2 of the ring, which is more labile than positions 4 and 5 [18], we also recorded the CID spectrum of 5 in the same solvent. The spectrum obtained for $\mathbf{5}$ (data not shown) was unmodified, proving that no exchange occurs on the ring under these conditions during the electrospray process.

The two main fragments obtained from the 1-methyl3-H-imidazolium ion in a previous study [19] at $m / z 42$ and 56 are observed here in the CID of $\mathbf{1}$ to 3 and are $\mathrm{C}_{2} \mathrm{H}_{4} \mathrm{~N}^{+}$and $\mathrm{C}_{3} \mathrm{H}_{6} \mathrm{~N}^{+}$, respectively, through accurate $\mathrm{MS}^{3}$ of $m / z$ 83. Figure 3a shows that as for $m / z 83$, by using a deuterated solvent, $m / z 56$ and 42 are split with $m / z 57$ and 43 arising if $W$ is a deuteron. Then, when $X$ is changed to $\mathrm{C}^{2} \mathrm{H}_{3}, m / z 56$ is further shifted to $m / z 59$ and further to 61 when $\mathrm{Y}$ is ${ }^{2} \mathrm{H}$ (Figure 2). With the labeling convention adopted in Table 1, these observations confirm $m / z 56$ ion is $\mathrm{C}_{2} \mathrm{NWXY}_{2}{ }^{+}$and for $m / z 42$ we have the two possibilities, $\mathrm{CNXY}^{+}$and $\mathrm{C}_{2} \mathrm{NWY}_{3}{ }^{+}$.

$M / z 95.0605\left(\mathrm{C}_{5} \mathrm{H}_{7} \mathrm{~N}_{2}{ }^{+}\right.$requires 95.0604$)$ in $\mathbf{1}$ is attributed to $\mathrm{a} b$ cleavage and is probably stabilized by ring expansion [20]. Its intensity decreases with the chain length and its position is shifted to $m / z 98$ and 101 in $\mathrm{C}^{2} \mathrm{H}_{3}$ and ${ }^{2} \mathrm{H}_{6}$ analogs, respectively, of 1 (Figure 2) to 3 , indicating that all labeling is conserved in this ion.
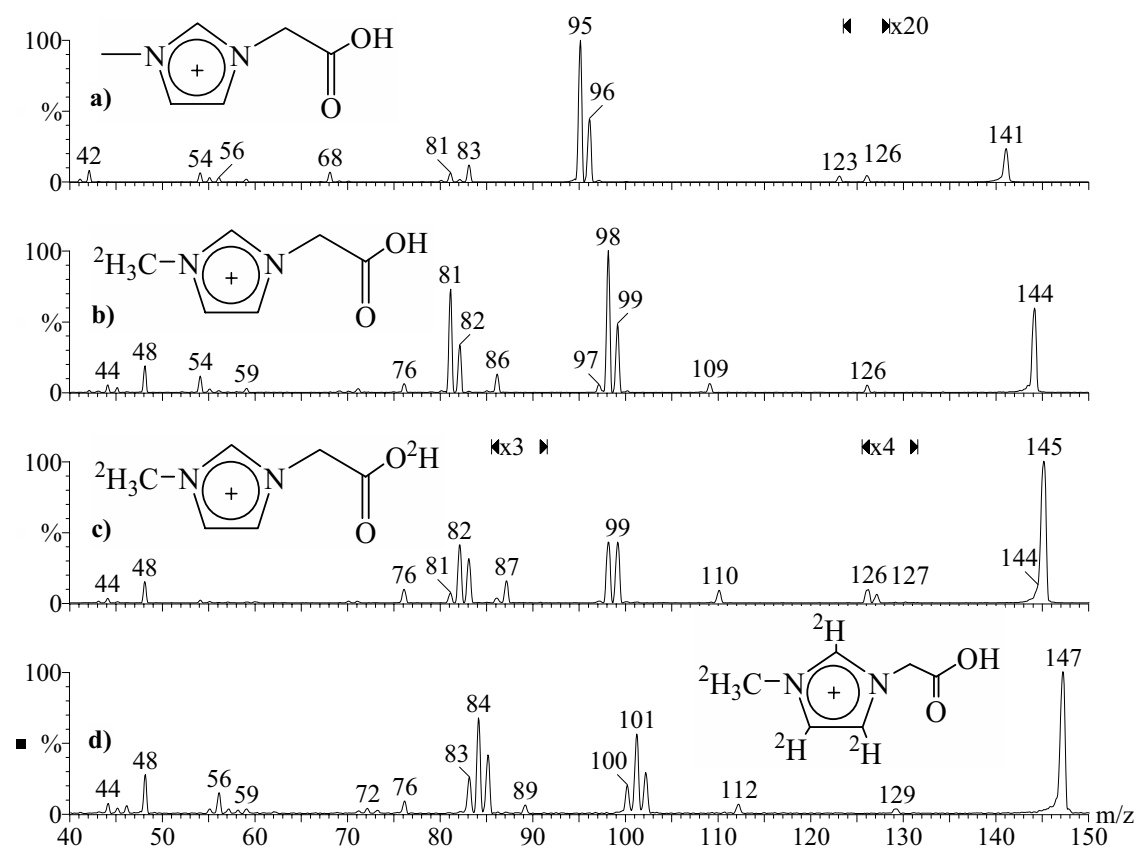

Figure 4. (a) $\mathrm{MS}^{2}$ spectrum of $m / z 141$ for 4. (b) $\mathrm{MS}^{2}$ spectrum of trideuteromethyl-substituted $\mathrm{m} / \mathrm{z}$ 144. (c) $\mathrm{MS}^{2}$ spectrum of trideuteromethyl-substituted 4 electrosprayed in deuterated solvent. $\mathrm{M} / z 126$ corresponds to the loss of ${ }^{2} \mathrm{HOH}$ from $\mathrm{m} / z 145$ and $\mathrm{m} / z 127$ results from the loss of $\mathrm{C}^{2} \mathrm{H}_{3}$ radical from $\mathrm{m} / \mathrm{z}$ 145. (d) $\mathrm{MS}^{2}$ spectrum of ${ }^{2} \mathrm{H}_{6}$-labeled 4 showing loss of ${ }^{2} \mathrm{H}$ from $\mathrm{m} / \mathrm{z} 102$ and 85 
Table 5. Accurate MS ${ }^{n}$ data (error: ppm) for Compounds 5-7. Ions correspond to those in Scheme 4

\begin{tabular}{|c|c|c|c|c|c|c|c|c|c|}
\hline & & Ion A & $\begin{array}{c}\text { Ion B } \\
\mathrm{C}_{7} \mathrm{H}_{4} \mathrm{IO}^{+} \\
\end{array}$ & $\begin{array}{l}\text { Ion } \mathrm{C} \\
\mathrm{C}_{6} \mathrm{H}_{4} \mathrm{I}^{+} \\
\end{array}$ & $\begin{array}{c}\text { Ion D } \\
\mathrm{C}_{9} \mathrm{H}_{8} \mathrm{O}_{2}^{+} \\
\end{array}$ & $\begin{array}{c}\text { Ion } \mathrm{E} \\
\mathrm{C}_{7} \mathrm{H}_{4} \mathrm{O}^{+}\end{array}$ & $\begin{array}{c}\text { Ion } \mathrm{F} \\
\mathrm{C}_{6} \mathrm{H}_{4}^{+\cdot}\end{array}$ & Ion $\mathrm{G}$ & $\begin{array}{c}\text { Ion } \mathrm{H} \\
\mathrm{C}_{4} \mathrm{H}_{7} \mathrm{~N}_{2}^{+} \\
\end{array}$ \\
\hline \multirow[t]{4}{*}{5} & $\mathrm{MS}^{2} 357$ & $\begin{array}{c}\mathrm{C}_{9} \mathrm{H}_{8} \mathrm{O}_{2} I^{+} \\
274.9562(-0.7)\end{array}$ & $\begin{array}{c}230.9299 \\
(-0.8)\end{array}$ & $\begin{array}{c}202.9351 \\
(-0.7)\end{array}$ & $\begin{array}{c}148.0519 \\
(0.0)\end{array}$ & $\begin{array}{c}104.0257 \\
(0.0)\end{array}$ & $\begin{array}{c}76.0308 \\
(0.1)\end{array}$ & nd & \\
\hline & $\mathrm{MS}^{3} 275$ & & $\begin{array}{c}230.9302 \\
(0.1)\end{array}$ & $\begin{array}{c}202.9352 \\
(0.0)\end{array}$ & $\begin{array}{c}148.0519 \\
(0.5)\end{array}$ & $\begin{array}{c}104.0257 \\
(0.3)\end{array}$ & $\begin{array}{c}76.0310 \\
(3.5)\end{array}$ & & \\
\hline & $\mathrm{MS}^{3} 231$ & & & $\begin{array}{c}202.9352 \\
(0.1)\end{array}$ & & $\begin{array}{c}104.0259 \\
(2.5)\end{array}$ & $\begin{array}{c}76.0310 \\
(3.5)\end{array}$ & & \\
\hline & $\mathrm{MS}^{4} 203$ & & & & & & $\begin{array}{c}76.0310 \\
(3.5)\end{array}$ & & \\
\hline \multirow[t]{3}{*}{6} & $\mathrm{MS}^{2} 371$ & $\begin{array}{c}\mathrm{C}_{10} \mathrm{H}_{10} \mathrm{O}_{2} \mathrm{I}^{+} \\
288.9725(1.7)\end{array}$ & $\begin{array}{c}230.9304 \\
(1.2)\end{array}$ & $\begin{array}{c}202.9354 \\
(1.0)\end{array}$ & & $\begin{array}{c}104.0258 \\
(1.1)\end{array}$ & $\begin{array}{c}76.0308 \\
(1.1)\end{array}$ & $\begin{array}{c}\mathrm{C}_{7} \mathrm{H}_{11} \mathrm{~N}_{2}{ }^{+} \\
123.0916(-0.3)\end{array}$ & \\
\hline & $\mathrm{MS}^{3} 289$ & & $\begin{array}{c}230.9301 \\
(-0.1)\end{array}$ & & & & & & \\
\hline & $\mathrm{MS}^{3} 231$ & & & $\begin{array}{c}202.9354 \\
(1.0)\end{array}$ & & $\begin{array}{c}104.0255 \\
(-2.0)\end{array}$ & $\begin{array}{c}76.0308 \\
(0.9)\end{array}$ & & \\
\hline \multirow[t]{3}{*}{7} & $\mathrm{MS}^{2} 413$ & & $\begin{array}{c}230.9305 \\
(1.7)\end{array}$ & $\begin{array}{c}202.9357 \\
(2.6)\end{array}$ & & & & $\begin{array}{c}\mathrm{C}_{10} \mathrm{H}_{17} \mathrm{~N}_{2}^{+} \\
165.1388(1.3)\end{array}$ & $\begin{array}{c}83.0605 \\
(1.2)\end{array}$ \\
\hline & $\mathrm{MS}^{3} 231$ & & & $\begin{array}{c}202.9354 \\
(0.9)\end{array}$ & & $\begin{array}{c}104.0264 \\
(7.0)\end{array}$ & $\begin{array}{c}76.0311 \\
(4.0)\end{array}$ & & \\
\hline & $\mathrm{MS}^{3} 165$ & & & & & & & & $\begin{array}{c}83.0604 \\
(0.0)\end{array}$ \\
\hline
\end{tabular}

nd: not detected

$\mathrm{M} / \mathrm{z} 96$ and 68 are observed only at higher $\mathrm{CE}$ and are, respectively, attributed to $\mathrm{C}_{5} \mathrm{H}_{8} \mathrm{~N}_{2}{ }^{+\cdot}$ and $\mathrm{C}_{3} \mathrm{H}_{4} \mathrm{~N}_{2}{ }^{+}$. through the use of labeling (Table 2). Radical cation $m / z$ 96 can only be formed directly from even electron $\mathrm{m} / \mathrm{z}$ 127 (by homolytic $\beta$-cleavage loss of $\mathrm{HOCH}_{2}$ ). Radical loss from an even electron ion is unusual. The breakdown graph for $\mathbf{1}$ shows that the onset of formation of $\mathrm{m} / \mathrm{z} 96$ is as low as $20 \mathrm{eV}$ (Figure 1). To further study the fragmentation of $m / z 95$ and 96 , we produced them

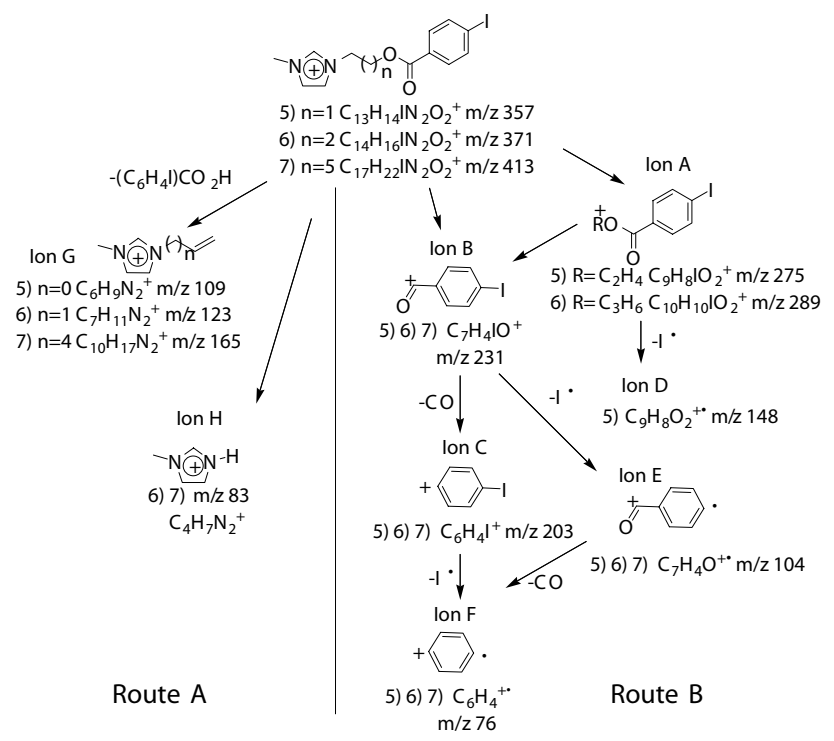

Scheme 4. Proposed fragmentation pathway for 5, 6, and 7 . from $\mathbf{1}$ in the source with a $75 \mathrm{~V}$ cone voltage. Their product ion scans are presented in Figure $2 \mathrm{~d}$ and e and demonstrate that radical cation $m / z 96$ undergoes $\mathrm{H}^{*}$ loss, and that $m / z 96$ and 95 both undergo methyl radical loss leading to $m / z 80$ and $m / z$ 81, respectively, even though $m / z 95$ is an even electron ion. It should be noted that fragmentation of both these ions leads to several common fragments.

Regarding fragments involving the alcohol function, the neutral loss of water expected for aliphatic alcohols is only a minor fragmentation pathway with, again, an intensity decreasing with chain length, and is found for 1 at $m / z 109.0760\left(\mathrm{C}_{6} \mathrm{H}_{9} \mathrm{~N}_{2}{ }^{+}\right.$requires 109.0760), for 2 at $m / z 123.0917\left(\mathrm{C}_{7} \mathrm{H}_{11} \mathrm{~N}_{2}{ }^{+}\right.$requires 123.0917), and is not detected for 3 . Whereas $\alpha$ cleavage of 1 leads to $\mathrm{m} / \mathrm{z}$ $45.0336\left(\mathrm{C}_{2} \mathrm{H}_{5} \mathrm{O}^{+}\right.$requires 45.0335$)$, which constitutes its second main fragment and for $2 \mathrm{~m} / z 59.0492\left(\mathrm{C}_{3} \mathrm{H}_{7} \mathrm{O}^{+}\right.$ requires 59.0491), which is less intense than for $\mathbf{1}$, for 3 an analogous ion is detected with difficulty at $\mathrm{m} / \mathrm{z}$ $101.0962\left(\mathrm{C}_{6} \mathrm{H}_{13} \mathrm{O}^{+}\right.$requires 101.0961). Labeling of the methyl group and the imidazole ring do not affect these masses whereas the use of a deuterated solvent shifts them 1 Da upward (Figure 3a for 1), confirming them as the result of cleavage a to the imidazole ring.

\section{Fragmentation of 4}

The proposed fragmentation pathway of 4 is presented in Scheme 3, which is supported by its breakdown graph (Supplementary Material), and by accurate mass 


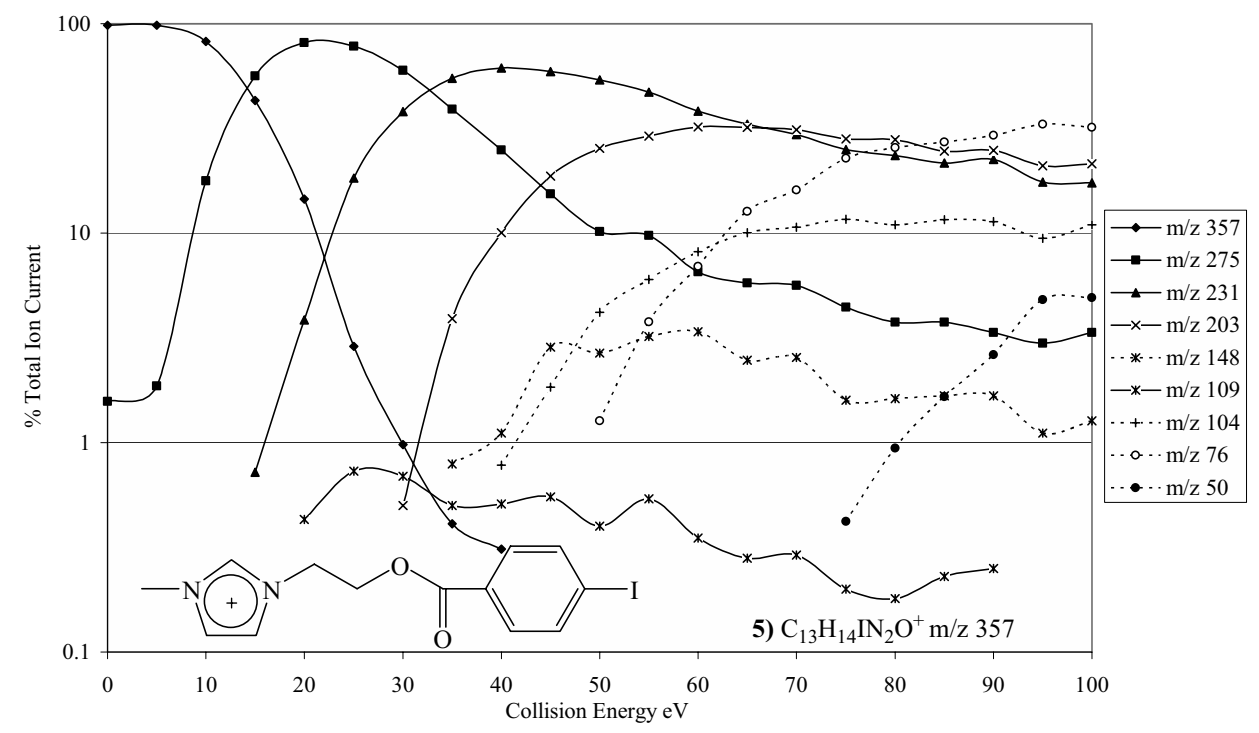

Figure 5. Breakdown graph for 5. Solid lines represent even electron ions, dotted lines represent odd electron ions.

data (Table 4) obtained in SORI-CID for $\mathbf{4}$ and its labeled analogs. As noted above in the breakdown graphs for $\mathbf{1}$ through $\mathbf{3}$, the intensity of the parent ion begins to decline at $15 \mathrm{eV}$ and remains constant above $30 \mathrm{eV}$, perhaps due to collision induced rearrangement to a more stable ion. However, the presence of a carboxylic acid function leads to a very different fragmentation pathway. Whereas for 1 to $3, \mathrm{~m} / \mathrm{z} 83$ was a major fragment for a wide range of collision energies, in the case of 4 this fragment only reaches $5 \%$ at $25 \mathrm{eV}$. Instead, the major fragmentation pathway for this compound leads to $\mathrm{m} / \mathrm{z} 95$ and 96 (Figure 4a), the former being the base peak above $25 \mathrm{eV}$. These ions were shown through their accurate mass to be $\mathrm{C}_{5} \mathrm{H}_{7} \mathrm{~N}_{2}{ }^{+}$and $\mathrm{C}_{5} \mathrm{H}_{8} \mathrm{~N}_{2}{ }^{+}$, respectively, (Table 4) and were increased, respectively, to $\mathrm{m} / z 98$ and 99 by $\mathrm{C}^{2} \mathrm{H}_{3}$ labeling (Figure $4 \mathrm{~b})$ and then to $\mathrm{m} / \mathrm{z} 101$ and 102 by additional ring labeling (Figure 4d). Their formation occurs through

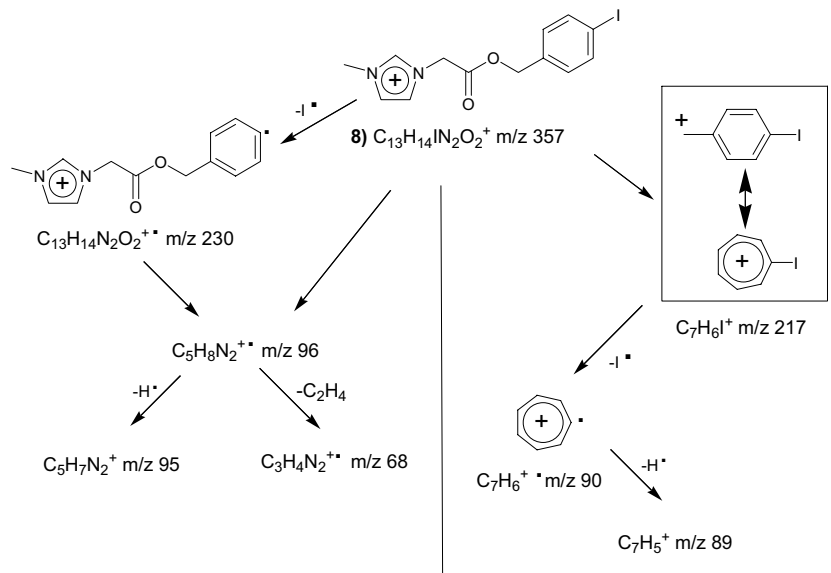

Route A

Route B loss of the carboxyl group by homolytic $\beta$-cleavage, specifically as $\mathrm{CO}_{2} \mathrm{H}$ to yield radical cation $\mathrm{m} / \mathrm{z} 96$ in the manner analogous to that in $\mathbf{1}$, while $\mathrm{m} / z$ 95 is formed by loss of formic acid. These two ions are very much more intense in 4 than in $\mathbf{1}$, which greatly facilitates the recording of accurate mass data for them and their CID fragments. The high intensity of $\mathrm{m} / \mathrm{z} 95$ may be due to rearrangement leading to a very stable aromatic structure [20] as suggested for $\mathbf{1}$. The loss of $\mathrm{CO}_{2} \mathrm{H}^{-}$(which may occur as successive or concerted losses of $\mathrm{H}$ and $\mathrm{CO}_{2}$ ) is unusual when it occurs from an even electron ion. The breakdown graph for $\mathbf{4}$ shows that the onset of formation of $\mathrm{m} / \mathrm{z} 96$ (the resulting radical cation) is as low as $15 \mathrm{eV}$ (Supplementary Material).

As observed for Compound 1, fragmentation of $m / z 95$ and 96 produced by cone voltage fragmentation (Supplementary Material) leads to proton and methyl radical losses. Here again, analogous ${ }^{2} \mathrm{H}$ loss is confirmed by the observation of ions at $m / z 97.0734\left(\mathrm{C}_{5} \mathrm{H}_{5}{ }^{2} \mathrm{H}_{2} \mathrm{~N}_{2}{ }^{+}\right.$requires 97.0729) and 100.0922 $\left(\mathrm{C}_{5} \mathrm{H}_{2}{ }^{2} \mathrm{H}_{5} \mathrm{~N}_{2}{ }^{+}\right.$requires 100.0918) in the ${ }^{2} \mathrm{H}_{3}$ and ${ }^{2} \mathrm{H}_{6}$ analogs of 4 from $\mathrm{m} / \mathrm{z} 99$ (Figure $4 \mathrm{c}$ ) and 102 (Figure $4 \mathrm{~d}$ ), respectively. The loss of $\mathrm{H}$; therefore, occurs from the methyl function on $\mathrm{N}^{\mathrm{I}}$, although there is evidence of scrambling (see below).

The processes leading to $\mathrm{m} / \mathrm{z} \quad 80$ and $\mathrm{m} / \mathrm{z}$ 81.0447 $\left(\mathrm{C}_{4} \mathrm{H}_{5} \mathrm{~N}_{2}{ }^{+}\right.$requires 81.0447) are not fully understood, although it is obvious that they occur through methyl radical loss (Figure 4e, f). The question of the proton source arises. First, in Figure $4 \mathrm{~b}$ the presence of $\mathrm{m} / \mathrm{z} 82$ suggests a loss of $17 \mathrm{Da}$ from $\mathrm{m} / \mathrm{z} 99$, which is not $\mathrm{C}^{2} \mathrm{H}_{3}$ but rather $\mathrm{C}^{2} \mathrm{H}_{2} \mathrm{H}$ and second, if we compare Figure $4 b$ and $c$ where the carboxylic acid proton is replaced by a deuteron, not only does a new ion at $\mathrm{m} / \mathrm{z}$ 83 appear but also the ratio between the ions at $\mathrm{m} / \mathrm{z} 98$ and $\mathrm{m} / \mathrm{z} 99$ is affected, suggesting some hydrogen scrambling in the ring expansion process forming a

Scheme 5. Proposed fragmentation pathway for 8. 
Table 6. Accurate $\mathrm{MS}^{\mathrm{n}}$ data for Compound 8 (error: ppm)

\begin{tabular}{lrrrrr}
\hline Composition & Calculated & \multicolumn{1}{c}{$\mathrm{MS}^{2} 357$} & $\mathrm{MS}^{3} 251$ & $\mathrm{MS}^{3} 230$ & $\mathrm{MS}^{3} 217$ \\
\hline \hline $\mathrm{C}_{9} \mathrm{H}_{8} \mathrm{O}_{2} \mathrm{I}^{+}$ & 274.9563 & $274.9564(0.2)$ & & & \\
$\mathrm{C}_{6} \mathrm{H}_{8} \mathrm{~N}_{2} \mathrm{OI}^{+}$ & 250.9676 & $250.9677(0.7)$ & & & \\
$\mathrm{C}_{13} \mathrm{H}_{14} \mathrm{~N}_{2} \mathrm{O}_{2}^{+\cdot}$ & 230.1050 & $230.1050(0.0)$ & & & \\
$\mathrm{C}_{7} \mathrm{H}_{6} \mathrm{I}^{+}$ & 216.9509 & $216.9509(0.3)$ & & \\
$\mathrm{C}_{5} \mathrm{H}_{8} \mathrm{~N}_{2}^{+\cdot}$ & 96.0682 & $96.0682(0.5)$ & $96.0683(0.6)$ & $96.0683(0.9)$ & $90.0464(0.4)$ \\
$\mathrm{C}_{5} \mathrm{H}_{7} \mathrm{~N}_{2}^{+}$ & 95.0604 & $95.0605(1.1)$ & $95.0605(1.3)$ & & $95.0604(0.1)$ \\
$\mathrm{C}_{7} \mathrm{H}_{6}{ }^{+}$ & 90.0464 & $90.0465(1.4)$ & & & \\
$\mathrm{C}_{7} \mathrm{H}_{5}{ }^{+}$ & 89.0386 & $89.0386(0.7)$ & & & \\
\hline
\end{tabular}

labeled analog of the $\mathrm{m} / \mathrm{z} 95$ ion noted in Scheme 2. In that case, $\mathrm{m} / \mathrm{z} 83$ could occur by $\mathrm{C}^{2} \mathrm{HH}_{2}$ loss from $\mathrm{m} / \mathrm{z}$ 99. Moreover, in Figure $4 \mathrm{~d} m / z 85$ can only be rationalized as the loss of $\mathrm{C}^{2} \mathrm{HH}_{2}$ from $\mathrm{m} / \mathrm{z} 102$.

The loss of water from $\mathrm{m} / \mathrm{z} 141$ leading to $\mathrm{m} / \mathrm{z}$ $123.0553\left(\mathrm{C}_{6} \mathrm{H}_{7} \mathrm{~N}_{2} \mathrm{O}^{+}\right.$requires 123.0553$)$ is confirmed by the observation of $m / z 126$ and $m / z 129$ in the ${ }^{2} \mathrm{H}_{3}$ and ${ }^{2} \mathrm{H}_{6}$ labeled analogs. We observe a very weak loss of methyl radical from $m / z 141$ (Figure 4a), and this loss from 144 in the cases of labeled 4 (Figure $4 \mathrm{~b}$ ) could be confused with the loss of water (both losses reduce the ion mass by $18 \mathrm{Da}$ ). When the ${ }^{2} \mathrm{H}_{3}$ analog was subjected to CID in deuterated medium, a loss of 19 Da was noted (Figure 4c), confirming that loss of methyl radical and water from $m / z 141$ are competing processes. In Figure $4 \mathrm{c}$ one can observe that, as for Compounds $\mathbf{1}$ to 3 , the use of deuterated solvent leads to the splitting of the $\mathrm{m} / \mathrm{z}$ 86 ion with $\mathrm{m} / \mathrm{z} 87$ being the most intense of the two, showing that the migrating proton is, as for $\mathbf{1}$, mainly taken from the carboxyl group.
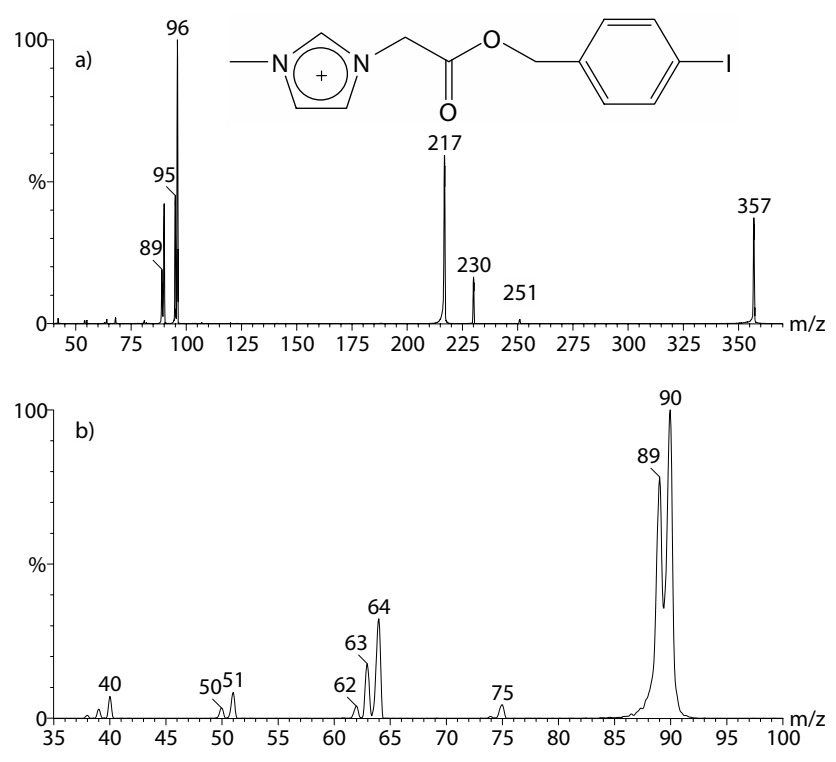

Figure 6. (a) $\mathrm{MS}^{2}$ spectrum of $\mathrm{m} / \mathrm{z} 357$ for 8 showing loss of I from the molecular cation $\left(\mathrm{m} / \mathrm{z}\right.$ 357. (b) $\mathrm{MS}^{2}$ spectrum of $\mathrm{m} / \mathrm{z} 90$ obtained by in source decomposition of 8 showing loss of $\mathrm{H}^{-}$and $\mathrm{CH}_{3}$ from $\mathrm{m} / \mathrm{z} 90$.

\section{Fragmentation of Esters 5, 6, and 7}

Compounds 5, 6, and 7 were obtained by esterification of $\mathbf{1}, \mathbf{2}$, and $\mathbf{3}$ with $p$-iodobenzoic acid [7c]. Accurate $\mathrm{MS}^{\mathrm{n}}$ data are presented in Table 5 and their fragmentation pathways are proposed in Scheme 4 . The breakdown graph of 5 presented in Figure 5, clearly shows that $\mathrm{m} / \mathrm{z}$ 357 fragments successively through $\mathrm{m} / \mathrm{z} 275,231,203$, and 76 . This succession is supported through accurate $\mathrm{MS}^{\mathrm{n}}$ data presented in Table 5. Similar behavior is noted for 6 and 7 (see breakdown graphs in Supplementary Material).

Two main fragmentation pathways are presented in Scheme 4 and supported through accurate MS $^{n}$ data in Table 5. Route A leads to ionic fragments derived from the imidazolium portion and Route B leads to fragment ions derived from the iodophenyl ester moiety.

Route $A$ is best represented by Compound 7 in which the first fragment $\mathrm{G}$ results from the $\alpha \beta$ elimination of iodobenzoic acid as seen for 5, 6, and $\mathbf{7}$ at $\mathrm{m} / \mathrm{z}$ 109,123 , and 165 , respectively. Their intensities increase with increasing aliphatic chain length. This is the only ion having appreciable intensity in the A pathway for $\mathbf{5}$. Secondly, proton transfer with side-chain elimination leads to the 1-methyl-3-H-imidazolium ion at $\mathrm{m} / \mathrm{z} 83$ which is the base peak for 7 above $25 \mathrm{eV}$, does not reach $1 \%$ of the TIC for $\mathbf{6}$, and is not seen for $\mathbf{5}$. As noted for Compound 3, a second ion of low intensity was found for 7 at $m / z 83.0857\left(\mathrm{C}_{6} \mathrm{H}_{11}{ }^{+}\right.$requires 83.0855) in the $\mathrm{MS}^{2}$ of $m / z 413$ and also in the $\mathrm{MS}^{3}$ of $\mathrm{m} / \mathrm{z} 165$.

For Route B, the heaviest fragment, A, obtained for $\mathbf{5}$ and $6(\mathrm{~m} / \mathrm{z} 275$ and 289, respectively, Scheme 4) with increasing $\mathrm{CE}$ is formed by a cleavage and loss of the imidazolium ring. In 5, in which two methylenes separate the imidazolium ring and the ester function, $\mathrm{m} / \mathrm{z}$ 275 reaches a greater abundance than $\mathbf{B}$, the iodobenzoyl ion at $\mathrm{m} / \mathrm{z} 231$, while in $\mathbf{6}$, three methylenes separate the two groups, and the analogous ion at $\mathrm{m} / \mathrm{z}$ 289 maximizes at an abundance lower than that for $\mathbf{B}$. The analogous ion at $\mathrm{m} / \mathrm{z} 331$ for 7 in which six methylenes intervene is not seen. For CE above $30 \mathrm{eV}$, B is formed directly by acyl-oxygen cleavage and becomes the base or a very intense peak for $\mathbf{5}$ and $\mathbf{6}$, whereas for 7 , its intensity only reaches $12 \%$ of TIC. Above $40 \mathrm{eV}, \mathrm{m} / \mathrm{z} 203$ is formed from B by carbon monoxide neutral loss whose intensity reaches more 
than $28 \%$ of the TIC for 5 and $\mathbf{6}$, whereas it is below $11 \%$ for 7. $M / z 148$ is formed by loss of iodo radical from $\mathrm{m} / \mathrm{z}$ 275 , and is seen only for 5, while iodo radical loss producing distonic radical cations $\mathrm{m} / \mathrm{z} 104$ and $\mathrm{m} / \mathrm{z}$ 76, E and $\mathbf{F}$, respectively, occurs for all three compounds, probably in the manner noted in the ESMS of iodo derivatives of coumarin [21]. The onset of formation of $\mathrm{E}$ and $\mathrm{F}$ are $\sim 40$ and $50 \mathrm{eV}$, respectively.

\section{Fragmentation of Compound 8}

Compound 8 was obtained by the esterification of the carboxylic acid function of 4 with iodobenzyl alcohol. Two main fragmentation routes are observed for this compound (Scheme 5), and these are supported by accurate mass data shown in Table 6 and by CID (Figure 6 and Supplementary Material).

In Route $\mathrm{A}$, the first fragment is formed starting at 10 eV by loss of iodine radical leading to $m / z 230$, it reaches maximum intensity at $20 \mathrm{eV}$, and it is not detected above $45 \mathrm{eV}$. In addition, we observe hydrogen and methyl radical losses from $\mathrm{m} / \mathrm{z} 95$ and 96 as described above. The onset of formation of $m / z 96$ from 8 is $15 \mathrm{eV}$ and it is the base peak in the interval from 20 to $45 \mathrm{eV}$ yielding $m / z 95$ by $\mathrm{H}$ radical loss above $25 \mathrm{eV}$.

The first ion to be formed via route B at $\mathrm{m} / z 217$ is attributed to the formation of an iodobenzyl ion. The well known stability of such ions allows this ion to remain as an intense peak in CID from $15 \mathrm{eV}$ up to 100 $\mathrm{eV}$.

A benzyl or tropylium radical cation at $\mathrm{m} / \mathrm{z} 90$ is formed by loss of an iodine radical from $\mathrm{m} / \mathrm{z} 217$ as demonstrated by $\mathrm{MS}^{3}$ (Table 6). CID of $m / z 90$ produced by in source fragmentation of 8 , presented in Figure $6 \mathrm{~b}$, shows that $m / z 89$ is formed by $\mathrm{H}$ radical loss from this radical cation. Evident also is the loss of methyl radical by $m / z$ 90; the mechanism of this loss is unknown.

\section{Conclusions}

Our study of the ESMS ${ }^{\mathrm{n}}$ behavior of several types of imidazolium ILs reveals many interesting routes of decomposition, some counter-intuitive and even surprising, presumably due to the presence of a permanent formal cationic charge. Several instances of $\mathrm{H}^{-}$loss are demonstrated from odd electron ions and confirmed by ${ }^{2} \mathrm{H}$ losses in deuterium labeled analogs. $\mathrm{CH}_{3}$ and $\mathrm{C}^{2} \mathrm{H}_{3}$ losses are also observed from even-electron ions, losses that are generally found in high-energy processes occurring in kilovolt regimes, not in electrospray-CIDtriple quadrupole systems. Homolytic charge remote cleavage of an iodine-carbon bond may have less energetic requirements, and several instances of this loss are noted. Collision-induced rearrangement of several ILs to ions resistant to decomposition at higher energies is apparent.

ILs 1 through 4 are useful as anchors for solution phase peptide synthesis [7d] and produce prominent fragments incorporating the imidazolium ring. On the other hand, for esters 5 to 7 , the relative importance of two main routes of fragmentation strongly depends on the number of methylenes between the ester function and the imidazolium ring. When this number is low, intense fragments arise by a charge-transfer to the ester moiety. At higher carbon number, imidazolium fragments and ions derived from them are predominant in the spectra.

This unusual transfer of charge to the ester moiety could be the basis for the derivatization of a variety of analytes with the imidazolium ring which may greatly improve their limits of detection by ESMS. The presence of their permanent formal positive charge, therefore, is an opportunity to be exploited in establishing sensitive analytical methods for them in ESMS and ESMS 2 .

\section{Acknowledgments}

The authors acknowledge the support of the Canadian Institutes of Health Research, Genome Quebec, and the Natural Science and Engineering Research Council of Canada.

\section{References}

1. (a) Holbrey, J. D.; Seddon, K. R. The phase behavior of 1-alkyl-3methylimidazolium tetrafluoroborates, ionic liquids and ionic liquid crystals. J. Chem. Soc. Dalton Trans. 1999, 19, 2133-2139; (b) Wilkes, J. S. A short story of ionic liquids-from molten salts to neoteric solvents. Green Chem. 2002, 4, 73-80; (c) Sheldon, R. Catalytic reactions in ionic liquids. Chem. Commun. 2001, 23, 2399-2407; (d) Sheldon, R. A.; Lau, R. M.; Sorgedrager, M. J.; van Rantwijk, F.; Seddon, K. R. Biocatalysis in ionic liquids. Green Chem. 2002, 4, 147-151; (e) Wasserscheid, P.; Keim, W. Ionic liquids-new "solutions" for transition metal catalysis. Angew. Chem. Int. Ed. 2000, 39, 3772-3789; (f) Forsyth, S. A.; Pringle, J. M.; MacFarlane, D. R. Ionic liquids-an overview. Aust. J. Chem. 2004, 57, 113-119; (g) Picquet, M.; Poinsot, D.; Stutzmann, S.; Tkatchenko, I.; Tommasi, I.; Wasserscheid, P.; Zimmerman, J. Ionic liquids: Media for better molecular catalysis. Topics Catalysis 2004, 29, 3-4, 139-143; (h) Wilkes, J. S. Properties of ionic liquids. Solvents for catalysis. J. Mol. Catal. A: Chem. 2004, 214, 11-17.

2. (a) Fuller, J.; Osteryoung, R. A. The room-temperature ionic liquid 1-ethyl-3-methylimidazolium tetrafluoroborate: Electrochemical couples and physical properties. J. Electrochem. Soc. 1997, 144, 3881-3886; (b) Fuller, J.; Breda, A. C.; Carlin, T. Ionic. liquid-polymer gel electrolytes from hydrophilic and hydrophobic ionic liquids. J. Electroanal. Chem. $1998,459,29-34$

3. (a) Huddleston, J. G.; Willauer, H. D.; Swatloski, R. P.; Visser, A. E.; Rogers, R. D. Room temperature ionic liquids as novel media for "clean" liquid-liquid extraction. Chem. Commun. 1998, 16, 1765-1766; (b) Visser, A. E.; Swatloski, R. P.; Reichert, W. M.; Mayton, R.; Sheff, S.; Wierzbicki, A.; Davis, J. H.; Rogers, R. D. Task-specific ionic liquids for the extraction of metal ions from aqueous solutions. Chem. Commun. 2001, 1, 135-136; (c) Bosmann, A.; Datsevich, L.; Jess, A.; Lauter, A.; Schmitz, C.; Wasserscheid, P. Deep desulfurization of diesel fuel by extraction with ionic liquids. Chem. Commun. 2001, 7, 2494-2495.

4. Ye, C.; Liu, W.; Chen, Y.; Yu, L. Room-temperature ionic liquids: A novel versatile lubricant. Chem. Commun. 2001, 21, 2244-2245.

5. Baker, G. A.; Baker S. N.; Pandey S.; Bright F. V. An analytical view of ionic liquids. Analyst 2005, 130, 800-808.

6. (a) Zabet-Moghaddam, M.; Kruger, R.; Heinzle, E.; Tholey, A. Matrixassisted laser desorption/ionization mass spectrometry for the characterization of ionic liquids and the analysis of amino acids, peptides, and proteins in ionic liquids. J. Mass Spectrom. 2004, 39, 1494-1515; (b) Li, Y. L.; Gross, M. L. Ionic-liquid matrices for quantitative analysis by MALDI-TOF mass spectrometry. J. Am. Soc. Mass Spectrom. 2004, 15, 1833-1837; (c) Li, Y. L.; Gross, M. L.; Hsu, F.-H. Ionic-liquid matrices for improved analysis of phospholipids by MALDI-TOF mass spectrometry. J. Am. Soc. Mass Spectrom. 2005, 16, 679-682; (d) Carda-Broch, S.; Berthod, A.; Armstrong, D. W. Ionic matrices for matrix-assisted laser desorption/ionization time-of-flight detection of DNA oligomers. Rapid Commun. Mass Spectrom. 2003, 17, 553-560.

7. (a) Fraga-Dubreuil, J.; Bazureau, J. P. Grafted ionic liquid-phase-supported synthesis of small organic molecules. Tetrahedron Lett. 2001, 42, 6097-6100; (b) Fraga-Dubreuil, J.; Bazureau, J. P. Efficient combination of task-specific ionic liquid and microwave dielectric heating applied to one-pot three component synthesis of a small library of 4-thiazolidinones. Tetrahedron 2003, 59, 6121-6130; (c) Miao, W.; Chan, T. H. Exploration of ionic liquids as soluble supports for organic synthesis. Dem- 
onstration with a Suzuki coupling reaction. Org. Lett. 2003, 5, 5003-5005; (d) Miao, W.; Chan, T. H. Ionic-liquid-supported peptide synthesis demonstrated by the synthesis of Leu ${ }^{5}$-enkephalin. J. Org. Chem. 2005 , 70, 3251-3255; (e) Davis, J. H. Task specific ionic liquids. Chem. Lett. 2004, 33, 1072-1077; (f) Yi, F.; Peng Y.; Song, G. Microwave-assisted liquid-phase synthesis of methyl 6-amino-5-cyano-4-aryl-2-methyl-4Hpyran-3-carboxylate using functional ionic liquid as soluble support. Tetrahedron Lett. 2005, 46, 3931-3933; (g) Wang, L.; Huang, Z. First application of ionic liquid to reactions involving organotellurium compounds as intermediates. J. Chem. Res. 2005, 7, 446-448.

8. Karkkainen, J.; Asikkala, J.; Laitenen, R. S.; Lajunen M. K. Effect of temperature on the purity of product in the preparation of 1-butyl-3methylimidazolium based ionic liquids. Z. Naturforsch. 2004, 59, 763-770.

9. (a) Alfassi, Z. B.; Huie, R. E.; Milman, B. L.; Neta, P. Electrospray ionization mass spectrometry of ionic liquids and determination of their solubility in water. Anal. Bioanal. Chem. 2003, 377, 159-164; (b) Milman, B. L.; Alfassi, Z. B. Detection and identification of cations and anions of ionic liquids using ESI MS and MS/MS. Eur. J. Mass Spectrom. 2005, 11, 35-42.

10. Jackson, G. P.; Duckworth, D. C. Electrospray mass spectrometry of undiluted ionic liquids. Chem. Commun. 2004, 5, 522-523.

11. Dyson, P. J.; Khalaila, I.; Luettgen, S.; McIndoe, J. S.; Dongbin, Z. Direct probe electrospray (and nanospray) ionization mass spectrometry of neat ionic liquids. Chem. Commun. 2004, 19, 2204-2205.

12. (a) Butcher, C. P. G. Energy-dependant electrospray ionization mass spectrometry. Aust. J. Chem. 2003, 56, 339; (b) Butcher, C. P. G.; Dyson, P. J.; Johnson, B. F. G.; Langridge-Smith, P. R. R.; McIndoe, J. S.; Whyte, C. On the use of breakdown graphs combined with energy-dependent mass spectrometry to provide a complete picture of fragmentation processes. Rapid Commun. Mass Spectrom. 2002, 16, 1595-1598.
13. Mamer, O. A. The thermolytic generation of benzofuran from ohydroxyacetophenone. Can. J. Chem. 1972, 50, 2513-2516.

14. Law, M. C.; Wong, K.-Y.; Chan, T. H. Solvent-free route to ionic liquid precursors using a water-moderated microwave process. Green Chem. 2002, 4, 328-330.

15. (a) Kimizuka, N.; Nakashima, T. Spontaneous self-assembly of glycolipid bilayer membranes in sugar-philic ionic liquids and formation of ionogels. Langmuir 2001, 17, 6759-6761; (b) Leone, A. M.; Weatherly, S. C.; Williams, M. E.; Thorp, H. H.; Murray, R. W. An ionic liquid form of DNA: Redox-active molten salts of nucleic acids. J. Am. Chem. Soc. 2001, 123, 218-222.

16. Gross J. H. Mass Spectrometry, 1st ed.; Springer-Verlag: Berlin, 2004; p 296.

17. Duffield, A. M.; Beugelmans, R.; Budzikiewicz, H.; Lightner, D. A.; Williams, D. H.; Djerassi, C. Mass spectrometry in structural and stereochemical problems. LXIII. Hydrogen rearrangements induced by electron impact on N-n-butyl and N-n-pentylpyrroles. J. Am. Chem. Soc. 1965, 87, 805-810.

18. Harris, T. M.; Randall, J. C. Deuterium exchange reactions at the 2-position of imidazoles. Chem. Ind. 1965, 41, 1728-1729.

19. Mamer, O. A.; Lesimple, A. Protonated 1-methylimidazole decomposition by electrospray tandem mass spectrometry. Rapid Commun. Mass Spectrom. 2005, 19, 1771-1774.

20. Porter, Q. N. Mass spectrometry of heterocyclic compounds, 2nd ed. In General Heterocyclic Chemistry Series; Taylor, E. C.; Weissberger, A., Eds.; John Wiley and Sons: New York, 1985; p 695.

21. Concannon, S.; Ramachandran, V. N.; Smyth, W. F. A study of the electrospray ionization of selected coumarin derivatives and their subsequent fragmentation using an ion trap mass spectrometer. Rapid Commun. Mass Spectrom. 2000, 14, 1157-1166. 